\title{
PENGARUH HARGA, PELAYANAN, LOKASI, DAN KERAGAMAN PRODUK TERHADAP KEPUTUSAN PEMBELIAN PADA HYPERMART PURI INDAH DI JAKARTA BARAT
}

\author{
Mimi S A dan Feliciana Daniaty \\ Falkutas Ekonomi Universitas Tarumangara \\ Email:mimi53.sa@gmail.com
}

\begin{abstract}
Abstrak: Penelitian ini dilakukan untuk mengetahui pengaruh harga, pelayanan, lokasi dan keragaman produk pada keputusan pembelian pada Hypermart Puri Indah di Jakarta Barat. Populasi pada penelitian ini merupakan konsumen yang berbelanja di Hypermart Puri Indah. Pada penelitian ini mengambil sampel sebanyak 100 responden. Metode yang digunakan dalam penelitian ini adalah metode convenience sampling non - probabilistik Temuan penelitian ini menunjukkan bahwa harga, layanan, tempat, dan keragaman produk signifikan terhadap keputusan pembelian di Hypermart.
\end{abstract}

Kata kunci: harga, pelayanan, lokasi, keragaman produk, keputusan pembelian

\begin{abstract}
This study was conducted to determine the effect of price, service, location and diversity of products on purchase decisions on Hypermart Puri Indah, West Jakarta. The population in this study are consumers who shop at Hypermart Puri Indah. In this study took a sample of 100 respondents. The method used in this study is a convenience sampling method non - probabilistic findings of this study indicate that the price, service, location and product diversity significantly influence purchasing decisions at Hypermart
\end{abstract}

Keywords: price, service, place, produk diversity, buying decision

\section{PENDAHULUAN}

Bisnis ritel atau usaha eceran mulai berkembang di Indonesia sekitar tahun 1980 seiring dengan perkembangan perekonomian Indonesia. Hal tersebut timbul akibat pertumbuhan yang terjadi pada masyarakat yang menyebabkan timbulnya permintaan terhadap supermarket di wilayah perkotaan. Salah satu toko ritel yang berkembang di Indonesia yaitu Hypermart, yang merupakan hasil revolusi alami dari toko ritel kecil tradisional, yang tadinya hanya menjual kebutuhan pokok sehari-hari, merupakan konsekuensi logis dari kemajuan industri ritel modern (R.Kasali, 2007). Berdasarkan data dari perusahaan Hypermart tahun 2013 (dalam Credit Suiise, 2014;7), Hypermart menguasai pangsa pasar sebesar 35.5\%, Carrefour 36.4\%, Giant sebesar $25.9 \%$ dan LotteMart sebesar $1.8 \%$.

Hypermart tercatat memiliki 112 gerai yang tersebar di seluruh Indonesia, gerai terakhir di buka di Lombok Epicentrum. Disamping banyaknya gerai yang di buka Hypermart memiliki competitor (pesaing) yang telah terlebih dahulu masuk ke dalam bisnis ritel di Indonesia, yaitu Carrefour yang telah memasuki pasar ritel Indonesia sejak tahun 1998, kemudian terdapat Hero, Giant, dan LotteMart.

Dengan banyaknya kompetitior yang telah terlebih dahulu masuk ke Indonesia, Hypermart harus memiliki keunggulan tersendiri yang membedakan dirinya dengan kompetitor-kompetitor lainnya. Menurut Crawford dan Benedetto (2006), harga merupakan bagian dari suatu produk, dimana harga yang dimaksud juga termasuk dalam bagian dari atribut produk dari pandangan pelangan. Dimana konsumen akan melihat harga sebelum memutuskan untuk membeli. Oleh maka itu dalam menentukan harga, sebuah perusahaan harus membuat analisa agar tepat sasaran. Dan dalam menentukan harga harus diimbangi dengan kualitas produk yang baik, sehingga konsumen akan merasa puas. 
Selain harga yang harus diperhatikan, terdapat faktor lain yang menunjang seorang konsumen dalam mengambil keputusan pembelian, anatara lain pelayanan, lokasi, keragaman produk, faktor lingkungan, budaya, maupun sosial.

Dalam hal pelayanan dan lokasi konsumen-konsumen yang datang ke Hypermarket juga mendapat kemudahan-kemudahan dalam berbelanja, seperti trolly utuk menaruh barang belanjaan, suasana nyaman (ruangan terang, sejuk, bersih dan luas), keleluasaan dalam memilih barang yang dibutuhkan, tata letak dan tata ruang dalam tempat belanja yang memudahkan konsumen menemukan barang yang dibutuhkan serta tersedia banyak kasir yang aktif serta memudahkan pembayaran.

Hypermart menunjukkan eksistensi pelayanan yang mereka berikan. Hal tersebut terbukti dengan menerima penghargaan Excellent Service Experince Award (ESEA) based in mystery shopper kategori ritel modern pada tahun 2014 yang diselenggarakan oleh Carre Center for Customer Satisfaction and Loyalty (Carre CCSL). Dan di tahun 2015 Hypermart kembali mendapatkan penghargaan Indonesia Best eMark Award 2015 dalam rangka memperingati the 2nd Anniversary Telkom University pada 10 September 2015 yang diselenggarakan dari Majalah SWABusiness Digest dan Telkom University.

Kotler dan Keller (2007:171) mengungkapkan keragaman produk pengecer harus sesuai dengan harapan belanja dari para sasarannya. Pengecer tersebut harus memutuskan keluasan dan kedalaman keragaman produk. Dengan demikian, suatu perusahaan dapat menawarkan keragaman produknya. Dalam hal ini Hypermart menjual berbagai macam lini, variasi, ukuran dan merek produk makanan, minuman dan elektronik. Sedangkan lokasi yang dipilih oleh Hypermart mayoritas berada dekat dengan kawasan perumahan, perkantoran, atau mall. Sehingga memudahkan konsumen dalam berbelanja.

Menurut penelitian dari Marno Nugroho, dan Ratih Paramita (2009) variabel lokasi, keragaman barang berpengaruh positif terhadap keputusan berbelanja dan loyalitas konsumen. Menurut penelitian dari Sasongko (2013) kualitas pelayanan, harga kompetitif, keragamanan barang, dan lokasi berpengaruh positif terhadap keputusan pembelian. Menurut Putri Mawar Fadmawati (2014) Harga, pelayanan, lokasi, dan keragamaan produk berpengaruh signifikan terhadap keputusan pembelian pada Minimarket Adina dimana variabel harga memiliki pengaruh yang lebih tinggi dibandingkan variabel lainnya

Permasalahan pada penelitian ini yaitu: (1) Apakah terdapat pengaruh harga terhadap keputusan pembelian pada Hypermart Puri Indah di Jakarta Barat?; (2) Apakah terdapat pengaruh pelayanan terhadap keputusan pembelian pada Hypermart Puri Indah di Jakarta Barat?; (3) Apakah terdapat pengaruh lokasi terhadap keputusan pembelian pada Hypermart Puri Indah di Jakarta Barat?; (4) Apakah terdapat pengaruh keragaman produk terhadap keputusan pembelian pada Hypermart Puri Indah di Jakarta Barat?; (5) Apakah terdapat pengaruh harga, pelayanan, lokasi, dan keragaman produk terhadap keputusan pembelian pada Hypermart Puri Indah di Jakarta Barat?

\section{KAJIAN TEORI}

Harga. Menurut Kolter \& Amstrong (2012) harga adalah sejumlah uang yang dibebankan atas suatu produk atau jasa atau jumlah dari nilai yang ditukarkan konsumen atas manfaat-manfaat karena memiliki atau menggunakan produk atau jasa tersebut. Fandy Tjiptono (2008:151) mengungkapkan harga merupakan satuan moneter atau ukuran lainnya termasuk barang dan jasa lainnya yang dapat ditukarkan agar memperoleh hak kepemilikan atau penggunaan suatu barang atau jasa.

Berdasarkan definisi-definisi yang di jelaskan beberapa ahli, dapat disimpulkan bahwa harga merupakan sejumlah uang yang ditukarkan atau di keluarkan untuk memperoleh, memiliki, dan menggunakan barang atau jasa. 
Pelayanan. Kotler (2012:214) mengartikan pelayanan sebagai berikut: "any act or performance that one party can offer another that is essensially intangible and does not result in the ownership of anything. It's production may or not be tied to a physical product".

Sedangkan menurut Fandy Tjiptono (2012:4) pelayanan (service) bisa dipandang sebagai sebuah sistem yang terdiri atas dua komponen utama, yakni service operations yang kerap kali tidak tampak atau tidak diketahui keberadaannya oleh pelanggan (back office atau backstage) dan service delivery yang biasanya tampak (visible) atau diketahui pelanggan (sering disebut pula front office atau frontstage).

Lokasi. Lokasi merupakan struktur fisik dari sebuah toko yang merupakan komponen utama dalam membentuk kesan sebuah konsumen terhadap sebuah toko. Oleh karena itu lokasi sangat penting dalam memposisikan toko retail kepada konsumen.

Kotler dan Amstrong (2012:63) mengartikan lokasi sebagai kegiatan perusahaan yang membuat produk tersedia bagi sasaran. Lokasi merupakan saluran distribusi yaitu serangkaian organisasi yang saling tergantung dan terlihat dalam proses untuk menjadikan produk atau jasa siap untuk digunakan atau dikonsumsi.

Keragaman Produk. Menurut Kotler dan Keller (2007: 15) mendefinisikan keragaman produk sebagai kumpulan daerah seluruh produk dan barang yang ditawarkan penjual tertentu kepada pembeli. Sedangkan menurut Utami (2010: 87) menjelaskan keragaman produk sebagai banyaknya item pilihan dalam masing-masing kategori produk.

Dari pengertian diatas dapat disimpulan bahwa kebergaman produk merupakan banyaknya item dalam masing-masing kategori produk yang ditawarkan penjual kepada pembeli. Semakin beragamnya jumlah dan jenis produk yang dijual di suatu tempat maka konsumen akan merasa puas, hal tersebut dikarenakan konsumen tidak perlu melakukan pembelian di tempat yang terpisah.

Keputusan Pembelian. Keputusan pembelian menurut Kotler dan Amstrong (2012:133):

"Consumer buyer behavior is the buying behavior of final consumer individuals and households who buys good and service for personal consumption."

Menurut Schiffman Kanuk yang dikutip oleh Novita Klarisa "Keputusan pembelian adalah pemilihan dari dua atau lebih alternatif pilihan keputusan pembelian "(Klarisa, 2013: 4) ,dapat juga diartikan bahwa seseorang dalam membuat keputusan harus memiliki beberapa alternatif pilihan.

Hubungan Harga terhadap Keputusan Pembelian. Faktor harga produk selalu menjadi faktor penting dalam proses dalam konteks setiap pembelian pelanggan/konsumen. Konsumen selalu memeriksa informasi harga dan nama merek berbeda ketika mereka membuat penilaian pada ukuran kualitas: kemudahan penggunaan, kegunaan, kinerja, ketahanan, dan status (Brucks, Zeithaml \& Naylor, dalam Rajput, et.al. 2012: 487).

Menurut Chang \& Wildt dalam Rajput, et.al (2012: 487) harga memiliki pengaruh yang signifikan yang dirasakan kualitas ketika satu-satunya informasi ditunjukkan tersedia. Menurut studi konsumen lebih suka untuk memiliki dengan harga dan kualitas daripada aspek-aspek teknis barang tahan lama (Chui, et. al. dalam Rajput, et.al. 2012: 487).

Hubungan Pelayanan terhadap Keputusan Pembelian. Menurut Brady dan Cronin (dalam Remiasa dan Lukman, 2007) persepsi pelanggan terhadap kualitas layanan ini terdiri dari tiga kualitas yaitu kualitas interaksi, kualitas lingkungan fisik dan kualitas hasil. Ketiga kualitas ini membentuk pada keseluruhan persepsi pelanggan terhadap kualitas layanan 
Hubungan Lokasi terhadap Keputusan Pembelian. Dalam bisnis, mencari dan menentukan lokasi merupakan tugas yang paling penting karena penentuan lokasi yang tepat merupakan kunci kesuksesan suatu bisnis. Faktor yang harus dipertimbangkan dalam menentuan lokasi, yaitu kestrategisan, apakah daerah tersebut dapat dijadikan pusat bisnis dan arus lalu lintas. Arus lalu lintas mempengaruhi penempatan lokasi usaha karena dapat menarik konsumen untuk mengunjungi bisnis tersebut dan bahkan juga memungkinkan konsumen untuk membeli (Utami, 2012:89). Konsumen cenderung memilih bisnis yang yang berlokasi di tempat yang mudah dijangkau, aman dan nyaman, dan memiliki area parkir yang luas. Lokasi yang strategis dapat mempengaruhi keputusan pembelian konsumen.

Hubungan Keragaman Produk terhadap Keputusan Pembelian. Keragaman produk memiliki hubungan erat dengan keputusan pembelian. Menurut Kotler dan Keller (2007:171) bahwa:

"Keragaman produk pengecer harus sesuai dengan harapan belanja dari para sasarannya. Pengecer tersebut harus memutuskan keluasan dan kedalaman keragaman produk. Dengan demikian, suatu perusahaan dapat menawarkan keragaman produknya."

Sedangkan menurut Asep (2005:9) mengatakan bahwa suatu kondisi tercipta dari ketersediaan barang dalam jumlah dan jenis yang sangat variatif sehingga menimbulkan banyaknya pilihan dalam proses belanja konsumen. Seringkali konsumen dalam proses belanjanya, mengambil suatu keputusan yang sebelumnya tidak tercantum dalam daftar belanja (out of purchase list).

Kerangka Berpikir dan Hipotesis. Kerangka berpikir pada penelitian ini terdapat pada gambar 1. Berdasarkan kerangka pemikiran maka hipotesis pada penelitian ini:

H1 : Terdapat pengaruh antara harga dengan keputusan pembelian

$\mathrm{H} 2$ : Terdapat pengaruh antara pelayanan dengan keputusan pembelian

H3 :Terdapat pengaruh antara lokasi dengan keputusan pembelian

$\mathrm{H} 4$ : Terdapat pengaruh antara keragaman produk dengan keputusan pembelian

H5 :Terdapat pengaruh antara harga, pelayanan, lokasi, dan keragaman produk terhadap keputusan pembelian

\section{METODE}

Sampel. Dalam penelitian ini teknik yang diambil oleh peneliti yaitu metode nonprobability sampling. Menurut Sugiyono (2010:120) non probablility sampling adalah teknik pengambilan sampel yang tidak memberi perluang atau kesempatan bagi setiap unsur atau anggota populasi untuk dipilih menjadi sampel. Teknik non probability sampling yang digunakan dalam penelitian ini adalah convinience sampling. Teknik convinience sampling ini merupakan teknik berdasarkan kebetulan, yaitu siapa saja yang secara kebetulan bertemu dengan peneliti dapat digunakan sebagai sampel, bila yang ditemui itu sesuai dengan sumber data.

Menurut Hair, et.al (2006) terdapat beberapa aturan dalam menentukan sampel, yaitu ukuran sampel tidak boleh kurang dari 50 responden, dan ukuran sampel lebih baik sama dengan 100 atau lebih. Oleh karena itu sampel yang diambil oleh peneliti adalah konsumen Hypermart di daerah Puri Indah, Jakarta Barat sebanyak 100 responden.

Metode pengumpulan data yang digunakan adalah dengan cara menyebarkan kuesioner kepada konsumen yang pernah berbelanja di Hypermart Puri Indah, Jakarta Barat. Dengan menyajikan pertanyaan tertutup yang memberikan alternatif jawaban. Skala yang dipakai dalam penyusunan kuesioner adalah skala Likert yang berisi lima tingkatan, sebagai berikut:

Sangat Tidak Setuju (STS) $=1$

Tidak Setuju (TS) $\quad=2$ 


$\begin{array}{ll}\text { Netral (N) } & =3 \\ \text { Setuju (S) } & =4 \\ \text { Sangat Setuju (SS) } & =5\end{array}$

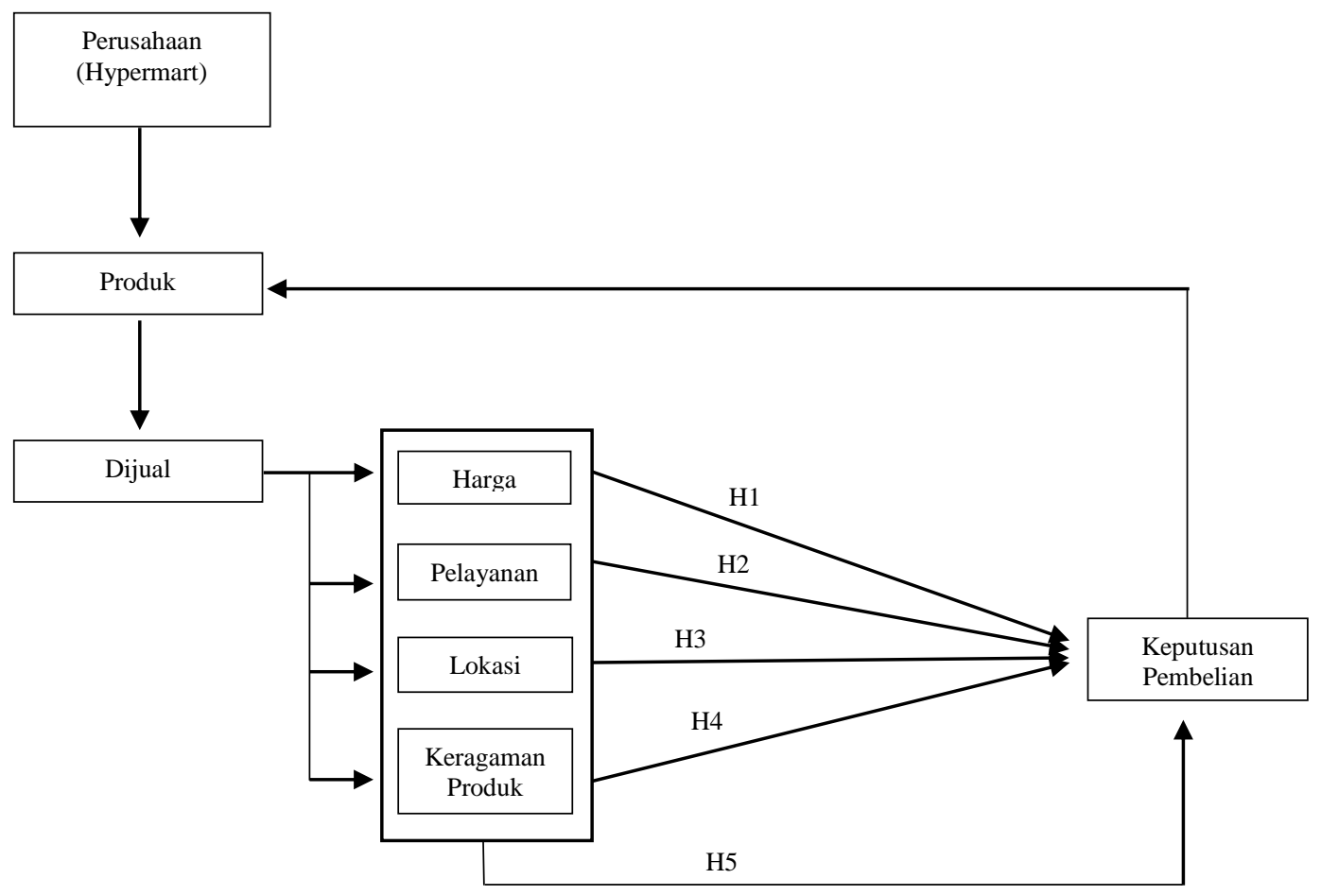

\section{Gambar 1. Kerangka Berpikir}

Teknik Analisa Data. Sebelum menganalisa pengaruh antar variabel dalam penelitian ini, peneliti terlebih dahulu menguji kelayakan pertanyaan dalam kuesioner dengan menggunakan uji validitas dan reliabilitas. Menurut Cronbanch (Aritonang, 2007:133) menyatakan bahwa korelasi skor suatu butir dengan skor totalnya minimal sebesar 0.2 agar dapat dinyatakan valid. Menurut Priyatno (2012:187) untuk menentukan suatu variabel reliable atau tidak maka bisa menggunakan rumus Cronbach's Alpha dengan melihat nilai Alpha 0.6.

Setelah pertanyaan setiap dalam setiap kuesioner valid dan reliabel, peneliti menguji asumsi klasik, yang terdiri dari dari uji normalitas, uji multikolinearitas, dan heteroskedastisitas. Suatu penelitian dikatakan normal jika memiliki nilai residual yang terdistribusi secara normal dengan tingkat signifikansi sebesar 5\%. Suatu penelitian dikatakan baik jika tidak memiliki multikolinearitas dengan melihat nilai $\mathrm{VIF}<10$, angka tolerance $>0.1$ dan tidak memiliki heteroskedastitas dengan melihat nilai absolute residual $>0,05$.

Untuk mengetahui hubungan secara linier antara dua atau lebih variabel independen dengan satu variabel dependen maka mengunakan analisa regresi linier berganda. Setelah mengetahui hubungan secara linier variabel independen terhadap dependen selanjutnya menguji pengaruh antar variabel independen terhadap variabel dependen, pengaruh variabel independen secara keseluruhan dan menganalisa seberapa besar pengaruh variabel independen terhadap variabel dependen. 


\section{HASIL DAN PEMBAHASAN}

Dari hasil uji validitas diketahui bahwa semua item pada masing-masing variabel dinyatakan valid, dan dari uji reliabilitas menunjukkan bahwa data yang terkumpul sudah reliabel. Hal ini menunjukkan bahwa instrumen dalam penelitian ini dapat dianalisa lebih lanjut. Dari hasil pengujian asumsi klasik diketahui bahwa model penelitian terdistribusi normal dan tidak terdapat gejala multikolinearitas maupun heteroskedastisitas.

Uji $\mathrm{F}$ bertujuan untuk mengetahui apakah terdapat pengaruh antara seluruh variabel independen terhadap variabel dependen

Tabel 1. Hasil Uji F

ANOVA $^{\mathrm{a}}$

\begin{tabular}{rlrrrrr}
\hline \multicolumn{1}{l}{ Model } & Sum of Squares & df & Mean Square & F & \multicolumn{1}{c}{ Sig. } \\
\hline \multirow{3}{*}{1} & Regression & 268.167 & 4 & 67.042 & 7.824 & $.000^{\mathrm{b}}$ \\
& Residual & 814.073 & 95 & 8.569 & & \\
& Total & 1082.240 & 99 & & &
\end{tabular}

a. Dependent Variable: keputusan_pembelian

b. Predictors: (Constant), keragaman_produk, Lokasi, Harga, Pelayanan

Berdasarkan hasil uji $\mathrm{F}$ pada Tabel 1, dapat disimpulkan bahwa nilai $\mathrm{F}$ hitung sebesar 7,824 dengan signifikansi 0.000 yang lebih kecil dari 0.05. Dengan hasil signifikansi sebesar 0.000 tersebut menunjukkan bahwa keempat variabel independen yaitu harga, kualitas pelayanan, lokasi, dan keragaman produk secara bersama-sama atau secara simultan berpengaruh signifikan terhadap keputusan pembelian, yang berarti bahwa H5 diterima.

Sedangkan untuk hasil uji t dapat dilihat pada tabel 2. Dimana Pengujian dilakukan dengan membandingkan nilai thitung dengan $t_{\text {tabel }}$ pada tingkat signifikansi 5\%. Apabila $t_{\text {hitung }}$ lebih besar dari $t_{\text {tabel }}$ maka hipotesis ditolak. Sebaliknya jika thitung lebih lebih kecil dari tabel maka hipotesis diterima.

Tabel 2. Hasil Uji t

\begin{tabular}{|c|c|c|}
\hline \multicolumn{3}{|c|}{ Coefficients $^{\mathbf{a}}$} \\
\hline Model & $\mathrm{t}$ & Sig. \\
\hline (Constant) & 2.542 & .013 \\
\hline Harga & 2.282 & .025 \\
\hline 1 Pelayanan & 2.762 & .007 \\
\hline Lokasi & 2.146 & .034 \\
\hline keragaman_produk & -1.985 & .050 \\
\hline
\end{tabular}

a. Dependent Variable: keputusan_pembelian

Pada Tabel 2 dapat dilihat bahwa nilai signifikansi variabel harga adalah 0,025. Hal ini berarti variabel harga mempengaruhi keputusan pembelian karena nilai signifikansi lebih kecil dari 0.05 . Sehingga dapat disimpulkan bahwa H1 tidak ditolak (diterima). Pada Tabel 2 dapat dilihat bahwa nilai signifikansi variabel kualitas pelayanan adalah 0,007. Hal ini berarti variabel kualitas pelayanan sangat mempengaruhi keputusan pembelian karena nilai signifikansi lebih kecil dari 0,05. Sehingga dapat disimpulkan bahwa $\mathrm{H} 2$ tidak ditolak (diterima). 
Pada Tabel 2 dapat dilihat bahwa nilai signifikansi variabel lokasi adalah 0,035. Hal ini berarti variabel lokasi mempengaruhi keputusan pembelian karena nilai signifikansi lebih kecil dari 0.05. Sehingga dapat disimpulkan bahwa H3 tidak ditolak (diterima). Pada Tabel 2 dapat dilihat bahwa nilai signifikansi variabel keragaman produk adalah 0,050 . Hal ini berarti variabel keragaman produk mempengaruhi keputusan pembelian karena nilai signifikansi lebih kecil dari 0.05. Sehingga dapat disimpulkan bahwa $\mathrm{H} 4$ tidak ditolak (diterima).

Dapat diambil kesimpulan dari Tabel diatas bahwa variabel yang sangat mempengaruhi variabel keputusan pembelian merupakan variabel kualitas penjualan.

Nilai $R$-square $\left(\mathrm{R}_{2}\right)$ digunakan untuk mengukur seberapa jauh kemampuan variabel-variabel independen dalam menerangkan variasi variabel dependen. Berdasarkan uji $R$-Square menunjukkan nilai adjusted $R$-square sebesar 0.216 atau 21,6\% variabel keputusan pembelian yang dapat dijelaskan oleh variabel independen, yaitu harga, pelayanan, lokasi, dan keragaman produk. Dan sisanya sebesar 78,4\% (100\%-21,6\%) dijelaskan oleh variabel lain.

\section{PENUTUP}

Kesimpulan. Berdasarkan hasil penelitian, dan pembahasan dapat ditarik kesimpulan sebagai berikut: Pertama, Harga berpengaruh terhadap keputusan pembelian, jadi apabila penetapan harga sesuai dan tepat maka keputusan pembelian akan meningkat Kedua, pelayanan berpengaruh terhadap keputusan pembelian. Sehingga dapat di artikan apabila pelayanan meningkat maka keputusan pembelian akan meningkat. Ketiga, lokasi berpengaruh terhadap keputusan pembelian. Sehingga apabila lokasinya strategis, nyaman dan aman maka keputusan pembelian pada lokasi tersebut akan meningkat. Keempat, keragaman produk berpengaruh pada keputusan pembelian. Apabila keragaman produk yang ditawarkan lengkap maka keputusan pembelian akan meningkat. Kelima, variabel harga, pelayanan, lokasi, dan keragaman produk berpengaruh signifikan terhadap keputusan pembelian.

Saran. Berdasarkan kesimpulan dari penelitian diatas, dapat dikemukakan saran-saran sebagai berikut: (1) Disarankan Hypermart selalu memperhatikan penetapan harga dengan cermat sehingga harga yang ditetapkan tidak mahal dan kompetitif. Hal tersebut dilakukan agar konsumen tidak memutuskan untuk berbelanja di tempat lain atau competitor Hypermart; (2) Disarankan Hypermart tetap mempertahankan kualitas pelayanannya dan terus meningkatkan kualitas pelayanannya. Upaya yang dapat dilakukan perusahaan untuk meningkatkan kualitas pelayanan karyawannya antara lain: (a) Memberikan pengarahan dan pelatihan bagaimana memberikan pelayanan bagi konsumen secara lebih mendalam; (b) Memberikan motivasi kepada karyawan dengan memberikan penghargaan; (c) Melakukan evaluasi terhadap pelayanan yang diberikan oleh karyawan setiap minggu atau bulan. (3) Disarankan Hypermart selalu memperhatikan dan memeriksa kesediaan keragaman produk yang ada di Hypermart. Dengan selalu mengisi kembali produk-produk yang akan atau sudah habis, sehingga konsumen tidak kecewa dan memutuskan untuk berbelanja di tempat lain.(4) Disarankan agara Hypermart selalu mejaga dan memperhatikan keamanan, kebersihan, dan kenyamanan di sekitar Hyperamart. Dengan melakukan pemeriksaan terhadap apakah CCTV di sekitar lapangan parkir masih berfungsi atau tidak, dan selalu memeriksa kebersihan disekitar Hypermart.

\section{DAFTAR RUJUKAN}

Arikunto, S. (2010) Prosedur penelitian: Suatu Pendekatan Praktik. Edisi Revisi. Jakarta: Rineka Cipta

Aritonang, R. Lerbin, R. (2007) Teori dan Praktik Riset Pemasaran. Ghalia Indonesia

Asep ST. Sujana. (2005) Paradigma Baru Dalam Manajemen Ritel Modern. Yogyakarta: Graha Ilmu. 
Basu, Swastha. (2010) Manajemen Pemasaran: Analisa dan Perilaku Konsumen. Yogyakarta: BPFE.

Ghozali, Imam. (2012) Aplikasi Multivariate dengan Program SPSS. Semarang: Badan Penerbit Universitas Diponegoro.

. (2013) Aplikasi Multivariate dengan Program. Edisi Ketujuh. Semarang: Badan Penerbit Universitas Diponegoro.

Griffin, Ricky. W. dan Ronald J. Ebert. (2008) Bisnis, Edisi Kedelapan, Jilid 1. Jakarta: Erlangga

Hair, J. F, Black, W. C., Babin, B.J, Anderson, R.E., \& Tathman, R. L., (2006) Multivariate data Analysis. Sixth Edition. New Jersey: Prentice Hall.

Kasali, Rhenald. (2007) Membidik Pasar Indonesia Segmentasi Targeting Positioning. Jakarta: PT Gramedia Pustaka Utama.

Kotler, Philip. (20012) Manajemen Pemasaran. Jakarta: PT. Index

PT. Index

dan Kevin Lane Keller. (2007) Manajemen Pemasaran 1. Edisi keduabelas. Jakarta:

Erlangga

.(2009) Manajemen Pemasaran. Jilid 1. Edisi 13. Jakarta:

Jakarta: Penerbit Erlangga

Education Limited, England.

. (2010) Manajemen Pemasaran Jilid 1. Edisi ketiga belas. (2012) Marketing Management, 14th Edition, Pearson Erlangga

Levy \& Weitz. (2007) Retail Management $6^{\text {th }}$ edition. Unites State of America: McGraw-Hill Internasional.

Novita Klarisa. (2013) Pengaruh Bauran Promosi Terhadap Keputusan Pembelian Konsumen Di Swalayan Maxi Balikpapan. Samarinda: Fakutas Ekonomi Universitas Mulawarman.

Priyatno, Duwi. (2012) Belajar Praktis Analisis Parametrik dan Non Parametrik dengan SPSS. Yogyakarta: Penerbit Gava Media.

Santoso, s. (2010) Statistik Multivariat Konsep dan Aplikasi dengan SPSS. Jakarta: PT. Elex Media Komputindo.

Sugiyono. (2012) Memahami Penelitian Kualitatif. Bandung: Alfabeta.

Schiffman, Leon G. Leslie, Lazar Kanuk. (2007) Perilaku Konsumen. Edisi 7. Cetakan kedua. Jakarta: Index.

Rajput, A.A.; Kalhoro, S.H.; dan Wasif, R. (2012) "Impact of Product Price and Quality on Consumer Buying Behavior: Evidence from Pakistan". Interdisciplinary Journal of Contemporary Research In Business. ijcrb.webs.com. 4 (4) August, 585-496.

Remiasa, Marcus. Dan Lukman, Yeni. (2007) "Analisis Persepsi Pelanggan Terhadap Kualitas Layanan Coffee Shop Asing dan Coffee Shop Lokal”. Jurnal Manajemen Perhotelan, 3, (2), 70-77.

Tjiptono, Fandy. (2011) Service Quality and Statisfaction. Edisi kedua. Yogyakarta: Penerbit Andi.

Andi Offset.

. (2012) Service Management Mewujudkan Layanan Prima. Yogyakarta: CV

Vinci, Maharani. (2009) Manajemen Bisnis Eceran. Bandung: Sinar Baru Algensindo.

Widya, Utami Christina. (2012) Manajemen Ritel dan Implementasi Ritel Modern. Jakarta 